\title{
ANALYSIS OF TECHNICAL EFFICIENCY, SOURCE OF INEFFICIENCY AND RISK PREFERENCES OF FARMERS AND ITS IMPLICATIONS IN THE EFFORTS TO IMPROVE PRODUCTIVITY OF PALM OIL PLANTATION IN JAMBI PROVINCE OF INDONESIA
}

\author{
Nainggolan Saidin*, Napitupulu D.M.T., Murdy Saad \\ Department of Agribusiness, Faculty of Agriculture, University of Jambi, Indonesia \\ *E-mail: saidinnainggolan@yahoo.com
}

\begin{abstract}
The purpose of this research: (1) To analysis the technical efficiency of the use of smallholder oil palm plantation inputs; (2) To find out the factors causing technical inefficiencies in the people's oil palm plantations; (3) To analyze the productivity risk behavior of oil palm farmers in Jambi Province; (4) Create a model (reconstruction) to increase the productivity of smallholder oil palm plantations. This research was carried out in Muaro Jambi, Batanghari, Sarolangun and Tebo Districts. Site selection is done purposively. The sample size was 280 farm households. The estimation method uses the Kumbhakar Production Function model with the stochastic frontier approach. The results showed that the use of production inputs both simultaneously and partially had a significant effect on Fresh Fruit Bunch production. All the uses of production inputs are classified as determinants of production. The use of production inputs has not been technically efficient $(E T<0.63)$, (chance of increasing production by $37 \%$ ). The source of technical inefficiency is significantly affected by the age of the farmer, the distance of the land, and the area of land, meaning that the further the distance of the land, the older the farmer is and the more extensive the land cultivated by the farmer, the more inefficient the oil palm farming is. The behavior of oil palm farmers in Jambi Region is a risk averter. The risk averse behavior of farmers has consequences for the allocation of inputs used. The more avoiding productivity risk, the less allocation of input use so that the productivity achieved by farmers is lower. The combined use of palm oil production inputs will affect the level of technical efficiency. The low average technical efficiency shows that the oil palm farmers' risk preferences affect technical efficiency. Increased productivity that takes into account the production function, risk function and profit function must use as much as optimal input usage so that productivity gains of 28 $49 \%$ are obtained.
\end{abstract}

\section{KEY WORDS}

Technical efficiency, technical inefficiency, farmer risk, stochastic frontier analysis.

Sub-sector of plantation in the future development will continue to play a strategic role both at the national and regional levels in the Jambi Region. Plantation sub-sector has a contribution to the utilization of natural resources (land), the provision of employment, the supply of industrial raw materials and the acquisition of added value, the increase in the country's foreign exchange through the export of plantation commodities and the increase in household income of farmers. In the future, the contribution of the plantation subsector will increasingly determine the structure of the economy. Plantation sub-sector is one part in the broad sense of agriculture.

For the Jambi area the agriculture sector absorbs labor is very important because the majority of the population is in rural areas and until now still relies on activities on smallholder plantations. The area of people's oil palm plantations in 2016 was 785,085 hectares. This area produces export volume and export value is very large for the Jambi Region. This shows that the people's oil palm plantations have the potential for the economy of the Jambi Region. The oil palm plantations of Jambi Province experienced extensive development of $4.2 \%$ per year and $4.8 \%$ production per year during the period 2005-2015. Research on oil palm states that the average productivity of oil palm plantations can reach 24-40 tons / ha / year. However, the productivity of oil palm in Jambi Province is only around 10-15 tons / ha / 
year, which means that it is very low from the highest technical efficiency. Smallholder oil palm plantations are very profitable for farmer economics but the achievement of farmers' income is very low. Low productivity figures occur because the oil palm commodity business is always constrained by the risk situation and uncertainty of farmers' socio-economic factors that ultimately affect technical efficiency. The use of a production factor is said to be technically efficient if the production factor used produces maximum production (Tasman, A 2008).

The low productivity of community oil palm plantations is thought to stem from the presence of production risks and low efficiency in the use of production inputs. The amount of production risk experienced by farmers will produce a response from farmers in the form of a preference for risk. Farmers' preferences in dealing with risks vary, there are farmers who are afraid or avoid risk (risk averse), dare to face risk (risk takers), and neutral against risk (risk neutral). Farmers who tend to be brave towards risk will increase the allocation of the use of production inputs, which in turn will have an impact on increasing productivity. Conversely, farmers' responses in the form of avoiding risks will reduce the allocation of inputs. The allocation of the use of production inputs in plantations affects the efficiency and productivity of smallholder oil palm plantations. Farmer risk preferences are influenced by production risks in the form of seasons, land, seeds, labor, fertilizer, and pepticides. This will affect the decision of farmers to allocate the use of inputs in accordance with the risks faced, the use of production inputs will affect the productivity of the oil palm plantations which leads to technical efficiency.

\section{METHODS OF RESEARCH}

The scope of the study area is Jambi Province with sample of 4 districts; Muaro Jambi, Batanghari, Sarolangun and Tebo district. The location of this research was chosen purposively with the consideration that the district is the center of community oil palm plantation.

Primary data collection methods are survey methods, observations, and direct interviews using questionnaires (written) to farmers to obtain information needed in research.

From each sample districts selected purposively, two sample villages were taken so that the number of sample villages was eight villages. Before sampling farmers, first make a sampling frame. From the sampling frame, it is known that the number of smallholder oil palm farmers in the study location was 3,346 farmers for eight sample villages. The sample groups that will be drawn as respondents are farmers who have a plant age of 6-10 years, 11-15 years, 16-20 years, 21-25 years. Determination of the number of samples used the formula Sugiarto (2003) as follows:

$$
\mathrm{n}=\frac{\mathrm{NZ}^{2} \mathrm{~S}^{2}}{\mathrm{ND}^{2}+\mathrm{Z}^{2} \mathrm{~S}^{2}}
$$

Where: $\mathrm{n}=$ number of samples; $\mathrm{N}=$ the number of members in the population (3.346); $Z=$ level of confidence $(95 \%=1,96) ; \mathrm{S} 2=$ sample of variant $(5 \%=0,05) ; D=$ degree of deviation (5\%).

The sample size was 280 farmers, from each sample village determined by the same allocation of 35 farmers. The sampling method is done premises Simple Random Sampling Methode and uses a random table.

To analyze the level of technical efficiency and productivity risk behavior of oil palm farmers using a model developed by Kumbhakar (2002). The functional form:

$$
Y i=\alpha_{0} \Pi_{j-i}^{8} X_{1}^{\infty}+\beta_{0} \Pi_{j-1}^{8} X_{1}^{n} \cdot e^{v i}-\gamma_{0} \Pi_{j-1}^{8} X_{1}^{n} \cdot e^{u i}
$$

Where:

$$
\alpha_{0} \Pi_{j-i}^{8} X_{1}^{\infty}: \text { Average production function; }
$$


$\beta_{0} \Pi_{j-1}^{8} X_{1}^{n} \cdot e^{v i}$ : Production risk function;

$\gamma_{0} \Pi_{j-1}^{8} X_{1}^{n} \cdot e^{u i}:$ Technical inefficiency function;

Yi: Total productivity of oil palm ( $\mathrm{kg} / \mathrm{ha})$;

$\mathrm{X}_{1}$ : The number of oil palm tree (tree/ha);

$\mathrm{X}_{2}$ : Total manpower (HKSP/ha);

$X_{3:}$ The amount of urea fertilizer $(\mathrm{kg} / \mathrm{ha})$;

$\mathrm{X}_{4}$ : The amount of TSP fertilizer $(\mathrm{kg} / \mathrm{ha})$;

$\mathrm{X}_{5}$ : The amount of MOP fertilizer $(\mathrm{kg} / \mathrm{ha})$;

$\mathrm{X}_{6}$ : The amount of Dolomite $(\mathrm{kg} / \mathrm{ha})$;

$X_{7}$ : The amount of kiserit $(\mathrm{kg} / \mathrm{ha})$;

$\mathrm{X}_{8}$ : Land area (ha);

$\mathrm{v}_{\mathrm{i}}$ : error term indicating production uncertainty assumed i.i.d $\left(0, \sigma_{u}\right)^{2}$;

$u_{i}$ : Technical inefficiency assumed i.i.d $\left(0, \sigma_{u}\right)^{2}$ and $u>0, u_{i}$ independent of $v_{i}$.

The expected sign for each parameter is $\alpha_{1}-\alpha_{8}>0 ; \beta_{1}-\beta_{8}>0$; and $\gamma_{1}-\gamma_{8}>0$. Model estimation is done used by maximum likelihood estimation (MLE) method.

Analysis of risk prevalence used the model of absolute risk aversion (AR), which is connected with the utility function owned by a farmer's utility $(U(\pi))$. The $\pi$ is formulated:

$$
\pi=p \cdot y-r \cdot x-C
$$

Where: $\pi=$ farm profits; $r=$ input price; $x=$ number of input used; $p=$ output price; $y=$ output; $\mathrm{C}=$ fixed cost.

Farming Output $(y)$ is formulated $y=f(x)+g(x)$ by substituted the farm output equation (y) into the farmer's utility equation then obtained:

$$
U(\pi)=p \cdot f(x)+p \cdot g(x)-r \cdot x-C
$$

Utility function $[\mathrm{U}(\pi)]$ is:

$$
U(\pi)=\operatorname{p.f}\left(x_{1}, \ldots ., x_{5}\right)+p . g\left(x_{1}, \ldots . ., x_{5}\right)-r i\left(x_{1}, \ldots . ., x_{5}\right)-C
$$

Where: $U(\pi)=$ farmer utility; $f(x)=$ production function; $g(x)=$ risk function; $p=$ output price (IDR); ri = input price to-i (IDR); $\mathrm{xi}=$ The amount of input to-l; $\mathrm{C}=$ fixed cost.

To analyze the value of farmers' risk preferences by adopted Arrow-Pratt absolute risk aversion (AR). The AR is formulated $A R=\left(U^{\prime \prime}(\pi)\right) /\left(U^{\prime}(\pi)\right)$. Decision makers are said to be risk averse if value of $A R(y)>0$, risk neutral if $A R(y)=0$, and risk taker if $A R(y)<0$ (Kumbhakar, 2002).

Technical inefficiency analysis uses a technical inefficiency effect model developed by Battese and Coelli (1995) in Coelli et al (1998).

$$
\mathrm{TI}=\varsigma 0+\mathrm{S} 1 \mathrm{Z}_{1}+\mathrm{S} 2 \mathrm{Z2}+\mathrm{S} 3 \mathrm{Z3}+\mathrm{S} 4 \mathrm{Z} 4+\mathrm{S} 5 \mathrm{Z} 5+\mathrm{S} 6 \mathrm{Z6}+\mathrm{S} 7 \mathrm{Z} 7+\mathrm{S} 8 \mathrm{Z} 8+\mathrm{Wi}
$$

Where:

$T_{1}$ : Value of technical inefficiency;

$Z_{1:}$ Land Area (ha);

$Z_{2:}$ Total revenue (IDR);

$Z_{3}$ : Age (year);

$Z_{4}$ : Education (year);

$Z_{5}$ : Farming experience (year);

$Z_{6}$ : The amount of family member (people);

$\mathrm{Z}_{7}$ : Land-house distance $(\mathrm{m})$;

$\mathrm{Z}_{8}$ : Group farmer;

Wi: Random error term which is assumed to be free and its distribution is truncated normally with $\mathrm{N}\left(0.0^{2}\right)$;

S: Effects of variables on technical inefficiency. 
The expected sign for each parameter of the effect of $S_{i}$ to $S_{4}$ inefficiency is negative while $S_{5}$ is expected to be positive.

For optimal use of inputs that can provide optimal production, Shephard-Lemma is used in Tasman, A (2008) and Lifianthi (2012), as follows:

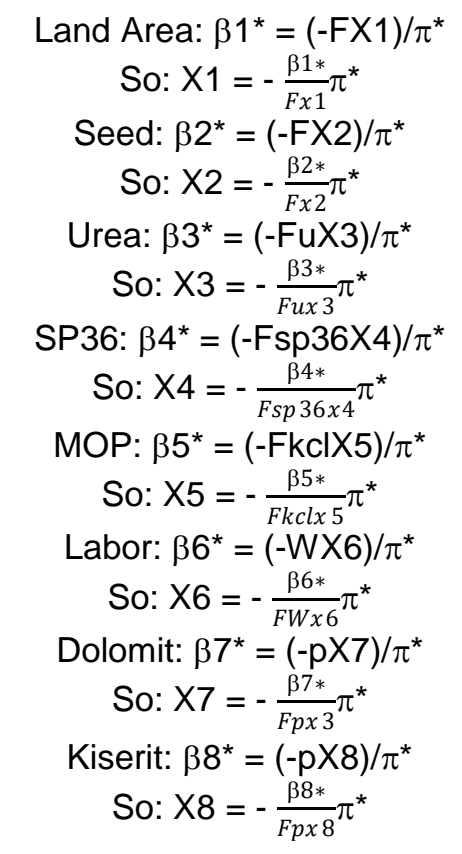

\section{RESULTS AND DISCUSSION}

The use of inputs is not optimal reflecting that the opportunity to increase productivity is quite large because the gap between the level of actual productivity with the maximum level of productivity that can be achieved with the best management system \{the best practiced\} is quite large. The average use of inputs and production between groups of farmers can be seen in Table 1.

Table 1 - The Use of Palm Oil Farm Production Input of Jambi Province, 2019

\begin{tabular}{lllllll}
\hline No & Faktor Produksi & Muaro Jambi & Batanghari & Sarolangun & Tebo & Jambi \\
\hline 1 & The amount of tree (stem/ha) & 126 & 125 & 120 & 122 & 123,33 \\
2 & Urea fertilizer (kg/ha) & 140,20 & 118,30 & 100,35 & 95,15 & 113,25 \\
3 & SP $_{36}$ fertilizer (kg/ha) & 85,28 & 75,34 & 60,56 & 60,45 & 70,53 \\
4 & MOP fertilizer (kg/ha) & 60,55 & 60,64 & 50,33 & 50,62 & 55,62 \\
5 & Dolomit $(\mathrm{kg} / \mathrm{ha})$ & 1100 & 800 & 700 & 650 & 812,5 \\
6 & Kiserit $(\mathrm{kg} / \mathrm{ha})$ & 70,50 & 65,62 & 60,44 & 60,72 & 63,75 \\
7 & Labor (HOK/ha) & 58,40 & 62,50 & 52,62 & 55,56 & 46,75 \\
\hline 8 & Land large (ha) & 5,20 & 4,60 & 3,80 & 4,30 & 4,50 \\
\hline
\end{tabular}

Table 1 shows that all production input uses are below the optimal dose, optimal urea fertilizer is around $275-300 \mathrm{~kg} / \mathrm{ha}, \mathrm{SP} 36$ fertilizer is $85-100 \mathrm{~kg} / \mathrm{ha}$, MOP fertilizer is $60 \mathrm{~kg} /$ ha, dolomite is $960 \mathrm{~kg} / \mathrm{ha}$. The average use of labor in the study area was $46.75 \mathrm{HOK} / \mathrm{ha}$. The average land use in the study area is 4.50 ha. This shows that the area of oil palm cultivated by farmers is relatively large.

The frontier productivity function is estimated using the stochastic frontier model with the Maximum Likeliood Estimation (MLE) estimation method which is carried out through a two-stage process. The first stage is the OLS method and the second stage uses the MLE method. The estimation results of the productivity function can be seen in Table 2 . 
Table 2 - Estimation Results of Palm Oil Farming Productivity Functions in Research by MLE Method, 2019

\begin{tabular}{cccccc}
\hline \multirow{2}{*}{ Variable } & \multicolumn{3}{c}{ Coefficient } \\
& Muaro Jambi & Batanghari & Sarolangun & Tebo & Jambi \\
\cline { 2 - 5 } The amount of tree (X1) & 0.413381 & 0.404041 & 0.357215 & 0.367742 & 0.385594 \\
& $(0.0101)$ & $(0.0190)$ & $(0.0101)$ & $(0.0190)$ & $(0.0145)$ \\
Urea (X2) & 0.379565 & 0.25655 & 0.415672 & 0.334562 & 0.446587 \\
& $(0.0042)$ & $(0.0088)$ & $(0.0042)$ & $(0.0088)$ & $(0.0065)$ \\
SP 36 (X3) & 0.011562 & 0.013633 & 0.035671 & 0.024351 & 0.21325 \\
& $(0.0011)$ & $(0.0004)$ & $(0.0011)$ & $(0.0004)$ & $(0.0007)$ \\
MOP (X4) & 0.202597 & 0.224968 & 0.250342 & 0.093527 & 0.292858 \\
& $(0.1246)$ & $(0.1116)$ & $(0.1246)$ & $(0.1116)$ & $(0.1181)$ \\
Dolomit (X5) & 0.230733 & 0.300926 & 0.353560 & 0.423567 & 0.327196 \\
& $(0.0004)$ & $(0.0361)$ & $(0.0004)$ & $(0.0361)$ & $(0.0182)$ \\
Kiserit (X6) & 0.264985 & 0.279952 & 0.193675 & 0.098776 & 0.209347 \\
& $(0.0052)$ & $(0.0464)$ & $(0.0052)$ & $(0.0464)$ & $(0.0258)$ \\
Labor $(X 7)$ & 0.143263 & 0.149134 & 0.188355 & 0.203345 & 0.171024 \\
& $(0.4117)$ & $(0.8719)$ & $(0.4117)$ & $(0.8719)$ & $(0.6418)$ \\
C & 5.405453 & 5.527277 & 9.533678 & 10.033452 & 7.624965 \\
& $(0.0000)$ & $(0.0000)$ & $(0.0000)$ & $(0.0000)$ & $(0.0000)$ \\
\hline Adj. ${ }^{2}$ & 0.94752 & 0.894777 & 0.89856 & 0.88672 & 0.911894 \\
\hline F count & 68,6764 & 66,6678 & 65,6745 & 64,3567 & 67,4782 \\
\hline Prob.F $F_{\text {stat }}$ & 0.0000 & 0.0000 & 0.0000 & 0.0000 & 0.0000 \\
\hline showed Sia & & & & &
\end{tabular}

Note: () $\rightarrow$ showed Sig.

Table 2 shows the value of Adj. $R^{2}=0.911894$, this means that $91.19 \%$ of production variation (output) can be explained together by the input production variables (number of trees, urea fertilizer, $\mathrm{SP}_{36}$ fertilizer, $\mathrm{MOP}$ fertilizer, dolomite, kiserit and labor while the remaining $8,81 \%$ are influenced by other factors outside the model. The productivity elasticity of the variable number of trees, urea fertilizer, SP36 fertilizer, MOP fertilizer, dolomite, kiserit and labor respectively were $0.3856 ; 0.4466 ; 0.2132 ; 0.2929 ; 0.3272$; $0.2093 ; .1710 ;$. If the variable number of trees, urea fertilizer, $\mathrm{SP}_{36}$ fertilizer, $\mathrm{MOP}$ fertilizer, dolomite, kiserit, and labor are added by $10 \%$ with the assumption that ceteris paribus can increase each productivity by $3.86 \% ; 4.47 \% ; 2.13 \% ; 2.93 \% ; 3.27 \% ; 2.09 \%$; and $1.71 \%$.

Value of $\beta i=1.845>1$; is in area II of the production curve, or the Increasing Return to Scale area. This means that each addition of production inputs in the same proportion of 10 percent will result in an additional increase in output (IRTS) of 10 percent. Variables that significantly affect productivity at the level $\propto=0.01$ are the number of trees, urea fertilizer, SP36 fertilizer, Dolomite and kiserit. While MOP fertilizer and labor have a significant effect on productivity at the level $\propto(0.05)$.

Table 3 - Technical Efficiency in Oil Palm Farming of Jambi Province, 2019

\begin{tabular}{ccc}
\hline Technical Efficiency & Jambi Area & $(\%)$ \\
\cline { 2 - 3 } & Numbers Of Farmers & 5,71 \\
$0,50-<0,55$ & 30 & 18,57 \\
$0,55-<0,60$ & 80 & 61,43 \\
$0,60-<0,65$ & 122 & 8,57 \\
$0,65-<0,70$ & 34 & 5,71 \\
$0,70-<0,75$ & 14 & 100,00 \\
\hline Total & 280 & \\
\hline Lowest Technical Efficiency & 0,5023 & \\
\hline Highest Technical Efficiency & 0,7452 & \\
\hline Average Technical & 0,6271 & \\
\hline
\end{tabular}

Technical efficiency is a reflection of the ability of farmers to obtain maximum output from a set of available inputs. Defined as the ratio of actual production from farmers at the technical level to the maximum possible production (frontier). The results of the analysis of technical efficiency in oil palm farming in Jambi Province can be seen in Table 3. 
Table 3, shows that the average level of technical efficiency in the Jambi Regional oil palm farming is 0.6271 . This shows that the average productivity achieved by oil palm farmers is around $62.71 \%$ of frontier production. The potential for increased production can still be increased by 0.3729 or by $37.29 \%$. The results of the technical efficiency analysis also showed that the lowest level of technical efficiency among oil palm farmers was 0.5023 and the highest was 0.7452 . This reflects that the opportunity to increase productivity is quite large because of the gap between the actual level of productivity that has been achieved by farmers and the potential for frontier production that is equal to $0.2548-.0 .4777 \%$.

Indications of production risk can be seen from the magnitude of the coefficient of variation (covariance). The coefficient value of the small production variation shows the variability of the low average value of production. This illustrates the risk of production faced to get production above a small average, and vice versa. The comparison of oil palm farming production risk between regions within Jambi Province can be seen in Table 4.

Table 4 - Productivity and Risk of Oil Palm Farming of Jambi Province, 2019

\begin{tabular}{cccccc}
\hline \multicolumn{5}{c}{ Palm Oil Productivity (ton / ha / year) } \\
\hline \multirow{2}{*}{ Regency } & \multicolumn{5}{c}{ Description } \\
\cline { 2 - 6 } & Muaro Jambi & Batanghari & Sarolangun & Tebo & Jambi \\
\hline Productivity & 15.200 & 10.350 & 9.855 & 8.780 & 11.046 \\
Std. Deviation & 3.855 & 2.975 & 2.150 & 1.985 & 2.741 \\
Covariance (\%) & 0,2536 & 0,2874 & 0,2181 & 0,2260 & 0,2462 \\
\hline
\end{tabular}

Table 4 shows that the magnitude of the coefficient of variation (KV) of Muaro Jambi Region is $\mathrm{KV}=25.36 \%$ Batanghari Region with $\mathrm{KV}=28.74 \%$, Sarolangun with KV of $21.81 \%$ and Tebo Region with $\mathrm{KV}$ of $22.60 \%$. This coefficient of variation indicates the magnitude of production risk. If the amount of $\mathrm{KV}$ is greater, it indicates a greater risk of production. The risk of oil palm production in the Jambi Region is relatively large. The average amount of KV $=24.62 \%$, this means that the magnitude of production variation is $24.62 \%$ of the average productivity and results in risk if $24.62 \%$ is below average productivity.

Measurement of production risk function in this study uses the Just and Pope method. The Just and Pope Production risk function model consists of a production function and a production variance function. The most common production risk function formula used in the Just and Pope Production risk model framework is the Cobb-Douglas function in the form of natural logarithms. To determine the risk of oil palm production in the use of palm oil production inputs can be analyzed using the Just and Pope Production risk function model. The results of the estimation of the production risk function can be seen in Table 5 .

Table 5 - Estimation Results of Risk Functions of Oil Palm Farming Production Production with Dummy of Jambi Province, 2019

\begin{tabular}{lllll}
\hline Variable & Coefficient & Std. Error & t-Statistic & Prob. \\
\hline X1_NUMBER OF TREES & $-0,208362$ & 0.076421 & -2.108387 & 0.0254 \\
X2_UREA & -0.165673 & 0.058435 & -2.223884 & 0.0243 \\
X3_SP36 & -0.138445 & 0.052436 & -2.432155 & 0.0115 \\
X4_MOP & 0.057646 & 0.063542 & 0.346149 & 0.0932 \\
X5_DOLOMITE & -0.096892 & 0.026785 & -1.289595 & 0.0864 \\
X6_KISERIT & -0.197643 & 0.046383 & -4.166071 & 0.0004 \\
X7_LABOR & 0.062454 & 0.035644 & 0.287166 & 0.0953 \\
X8_LAND AREA & 2.745633 & 0.106478 & 27.10045 & 0.0000 \\
DUMMY & 0.225674 & 0.043543 & 6.879039 & 0.0000 \\
C & 18.87453 & 0.048667 & 43.45849 & 0.0000 \\
\hline R-squard & 0.953175 & & & \\
\hline Adjusted R-Squared & 0.964667 & & & \\
\hline F Count & 67,8562 & & \\
\hline Prob.F & 0.0000 & & & \\
\hline
\end{tabular}

Table 5 shows that the results of the estimation of the production risk function model provide a coefficient of determination $\left(\mathrm{Adj}-\mathrm{R}^{2}\right.$ ) of 0.964667 . This shows that $96.47 \%$ of the diversity of oil palm production risk can be explained jointly by the production inputs for the 
amount of tree, urea fertilizer, $\mathrm{SP}_{36}$ fertilizer, MOP fertilizer, dolomite, kiserit, labor and land area, while the remaining $3.53 \%$ is explained by other factors outside the model.

The results of the analysis of technical efficiency that have not been achieved indicate that the use of inputs is still influenced by other factors outside the model. Factors that can limit the achievement of maximum results are called irregularities in farming. Deviations from Isoquant frontier are called technical inefficiencies. There are many factors that influence the not achieving technical efficiency in the production process, one of which is a socioeconomic factor. Based on Table 10, it can be seen that the variables that significantly influence the technical inefficiencies in oil palm farming at $\alpha=5 \%$ are age, palm oil farming experience, distance between houses to land and land area. While the variables that have no significant effect in explaining the sources of technical inefficiencies in farming are education, number of family members and activeness in farmer groups. Sources of technical inefficiency can be seen in Table 6 below.

Table 6 - Estimated Results of Sources of Technical Inefficiency in Palm Oil Farms of Jambi Province, 2019

\begin{tabular}{lllll}
\hline Variable & Coefficient & Std. Error & t-Statistic & Prob. \\
\hline Z1 - AGE & 0.049153 & 0.010060 & 4.885860 & 0.0000 \\
Z2 - EDUCATION & -0.002073 & 0.002406 & -0.861731 & 0.3917 \\
Z3 - EXPERIENCE & -0.019006 & 0.007263 & -2.616692 & 0.0108 \\
Z4 - JAK & -0.007897 & 0.006898 & -1.144836 & 0.2561 \\
DZ5-KDKT & -0.001110 & 0.004904 & -0.226328 & 0.8216 \\
Z6 - JLRT & 0.006147 & 0.002158 & 2.847952 & 0.0057 \\
Z7 - LAND AREA & 0.021228 & 0.006025 & 3.523532 & 0.0007 \\
C & 0.259444 & 0.045878 & 5.655035 & 0.0000 \\
\hline Adj. R & 0,7478 & & \\
\hline F Count & 47,667 & & \\
\hline Prob. F & 0.0000 & & & \\
\hline
\end{tabular}

The results of the analysis of frontier productivity functions, production risk are used to analyze the risk preferences of oil palm farmers. Based on the analysis of the risk preferences of oil palm farmers in Jambi Province, the overall production input is the number of trees, urea fertilizer, SP36 fertilizer, MOP fertilizer, Dolomite, kiserit, and labor, the average value of $\theta$ farmers is -0.016 and the average value $\lambda$ is 1.995 in the Muaro Jambi oil palm farm, while in the Batanghari oil palm farm the average value of $\theta$ farmers is -0.204 and the average value of $\lambda$ is 2.641. These results indicate that the average productivity risk of oil palm farmers towards production inputs is risk aversion; the results of this study are not in line with NatasaApriana's (2015) research which shows that the average risk preferences of farmers are risk takers.

Table 7 - Productivity preferences of oil palm farmers of Jambi Province, 2019

\begin{tabular}{llll}
\hline Muaro Jambi Regency & & & \\
\hline Production Input & Average Value $\theta$ & Average value $\lambda$ & Risk Preferences \\
\hline Number of trees & 2,356 & 1,795 & Risk Taker \\
Urea & $-0,854$ & 2,837 & Risk Averter \\
$\mathrm{SP}_{36}$ & 0,796 & 4,386 & Risk Taker \\
$\mathrm{MOP}$ & $-0,878$ & 3,016 & Risk Averter \\
Dolomite & $-1,154$ & 1,153 & Risk Averter \\
Kiserit & 0,223 & 2,852 & Risk Averter \\
Labor & 0,131 & 0,148 & Risk Taker \\
\hline Average & $-0,016$ & 1,995 & Risk Averter \\
\hline
\end{tabular}

Farmers decisions that are risk averse (impact risk) impact on the allocation of inputs used. Farmers who are risk averse will allocate smaller production inputs when compared to farmers who are risk takers so that production is also low. The results of the analysis of risk preferences of oil palm farmers in Jambi Province by using a risk preference analysis model (Kumbhakar, 2002) yields a value of $\theta$ and $\lambda$ that can be seen in Table 7. 
The maximum profit that is difficult for farmers to achieve can be due to several things: (1) farmers do not or do not understand the principle of the relationship of input and output. causing low actual production; (2) farmers are often faced with high risk; (3) farmers are often faced with price uncertainty in the future; (4) limitations of farmers in providing fertilizer due to limited capital and skills of farmers. Factors of input and output price of farming will affect the amount of profit of farmers. The results of estimating the profit function of the Unit Output Price (UOP) can be seen in table 8.

Table 8 - Results of Estimated Benefits Function of Oil Palm Farming, 2019

\begin{tabular}{lll}
\hline Regression & Coefficient Variable & Sig. \\
\hline Land lease & 0,5456 & 0,0022 \\
Price of Seeds & $-0,2752$ & 0,0256 \\
Price of urea fertilizer & 0,8556 & 0,0001 \\
SP 36 fertilizer price & 0,3562 & 0,0164 \\
Labor prices & $-2,5778$ & 0,0000 \\
MOP fertilizer price & $-3,8645$ & 0,0000 \\
Dolomite Prices & $-0,6742$ & 0,0018 \\
Price of kiserit & 1,6772 & 0,0000 \\
January-Jun dummy & 27,4563 & 0,0000 \\
Dummy for Jul-Dec & $-25,4113$ & 0,0000 \\
Intercept & 0,6135 & \\
\hline Adj. R2 & 0,8240 & \\
\hline F count & 36.422 & \\
\hline Prob. F $_{\text {stat }}$ & 0,0000 & \\
\hline
\end{tabular}

If it is associated with the productivity function, risk function and profit function with the estimated results of the frontier productivity function, then the optimal allocation of input uses can be determined.

$$
\begin{aligned}
& \operatorname{Ln} Y=7,62+0,39 \operatorname{LnX} 1+0,35 \operatorname{LnX} 2+0,02 \operatorname{LnX} 3+0,19 \operatorname{LnX} 4+0,33 \operatorname{LnX} 5+0,21 \operatorname{LnX} 6+0,17 \operatorname{LnX} 7 \\
& \operatorname{Ln} Y_{\text {(risk) }}=21,16-0,19 \operatorname{LnX} 1-0,15 \operatorname{LnX} 2-0,14 \operatorname{LnX} 3+0,02 \operatorname{LnX} 4-0,06 \operatorname{LnX} 5-0,19 \operatorname{LnX} 6-0,02 \\
& \operatorname{LnX7}+2,82 \operatorname{Ln} X 8-0,21 \text { Dummy } \\
& \operatorname{Ln} \pi=0,6135+0,55 \times 1-0,28 \times 2+0,86 \text { X3 }+0,36 \text { X4 }-2,58 \times 5-3,86 \text { X6 - 0,68 X7 }+1,68 \text { X8 }+27,46 \\
& \text { Dja }-25,4 \text { Dju }
\end{aligned}
$$

Using the following Hotteling's-Lemma approach method:

$$
\mathrm{X}^{*}=\frac{\beta^{*} P y^{*} y^{*}}{P_{X}}
$$

And use a confidence interval:

$$
\mathrm{P}\left(\mathrm{X}^{*}-\mathrm{t}(\propto=5 \% d b=n-1) \frac{s}{\sqrt{n-1}}<\mu<X^{*}+t(\propto=5 \% d b=n-1) \frac{s}{\sqrt{n-1}}=1-\propto\right)
$$

Table 9 - Comparison of the Use of Actual and Optimal Inputs in Oil Palm Farming of Jambi Province

\begin{tabular}{ccc}
\hline Input Types & \multicolumn{2}{c}{ Use Inputs } \\
\cline { 2 - 3 } & $\mathrm{X}_{\text {Actual }}$ & $\mathrm{X}_{\text {Optimal }}$ \\
\hline Land Large (ha) & 4,50 & 7,80 \\
Number of trees (btg) & 122,33 & $133-156$ \\
Urea (kg) & 113,25 & $150-225$ \\
SP36 (kg) & 70,53 & $120-180$ \\
MOP (kg) & 55,62 & $65-110$ \\
Labor (HOK) & 46,75 & $50-62$ \\
Dolomite (kg) & 812,50 & $900-1200$ \\
Kiserit (kg) & 63,75 & $80-140$ \\
Production (tons) & 9,42 & $14,26<\mathrm{Y}$ opt $<26,73$ \\
\hline
\end{tabular}


Then the results obtained from the estimation of the use of optimal production inputs as Table 9. It shows that the use of actual inputs is below the optimal use of inputs, so in order to achieve optimal production; farmers need to allocate as much input as optimal Xi. The actual production obtained is 9.42 tons / ha and the optimal production is $14.26<\mathrm{Y}$ opt $<26.73$ tons / ha. If farmers want to get the maximum profit, farmers must allocate production inputs with a combination of the optimal amount and the right fertilization time so that production is obtained close to frontier production.

\section{CONCLUSION}

The productivity function of oil palm farming produces low technical efficiency, which means that there is still a significant opportunity to increase production; technical efficiency is very responsive to all production inputs, especially on land area, number of trees, and urea fertilizer. Farmer's productivity risk behavior towards production inputs on average is risk averse. This means that if there is an increase in the price of production inputs, farmers as decision makers will compensate by reducing the expected benefits or reducing the amount of use of production inputs. Policies that need to be considered in the context of increasing oil palm production, namely: increasing productivity through the application of appropriate technologies in cultivation that pay attention to agronomic and climatological aspects, expanding the area of oil palm plantations, reducing crop loss and, increasing yield stability by implementing integrated crop management, pressing gaps the results of productivity at the farm level and productivity of research results through the application of the technology transfer process for location specifications and farm capital support. The success of increasing productivity needs to be supported by an appropriate subsidy policy and accompanied by increasing production input kiosks for farmers because farmers are classified as lacking access or partnership networks, and have limited working capital for farming. The subsidies in question are in the form of fertilizer price subsidies and capital interest subsidies in the form of farm credit with low interest rates and easier procedures for farmers, so that it will reduce production risks that arise from the use of production inputs and ultimately will increase technical efficiency that benefits farmers.

\section{REFERENCES}

1. Antle, J.M. 1987. Econometric Estimation of Producer's Risk Attitude. American Journal of Agricultural Economics, 69(3): 509-522.

2. Badan Pusat Statistik. 2015. Jambi Dalam Angka 2015. Badan Pusat Statistik Provinsi Jambi. Jambi.

3. BALITBANG. 2015. Prospek and arah pengembangan agribisnis kelapa sawit. http:www.litbang.pertanian.go.id/special/komoditas/files/0104-KELAPA SAWIT.pdf. (Diakses 10 November 2016).

4. Daryanto, H.K.S. 2000.Analisys of ThecnicalEfisiensy of Rice Production In West Java Province, Indonesia: A Stochastic Frontiner Production Function Approach. PhdDisertation. School Economics, Umiversity New England, Armidale.

5. Kumbhakar, C.S. 2002. Spesification and Estimation of Production Risk, Risk Preference and Tehnical Efficiency. American Journal of Agricultural Economics, 84(1): 8-22.

6. Nurhapsa. 2013. Analisis Efisiensi Teknis and Perilaku Risiko Petani Serta Pengaruhnya Terhadap Penerapan Varietas Unggul Pada Usahatani Kentang Di Kabupaten Enrekang Provinsi Sulawesi Selatan. Tesis (Dipublikasikan). Ilmu Ekonomi Pertanian. Program Pasca Sarjana Institut Pertanian Bogor, Bogor. Diunduh dari: http://repository.ipb.ac.id/jspui/bitstream/123456789/66823/1/2013nur.pdf. (Diakses pada tanggal 12 November 2016).

7. Qomaria, Nurul. 2011. Analisis Preferensi Risiko and Efisiensi Teknis Usahatani Talas Di Kota Bogor. Tesis (Dipublikasikan). Ilmu Ekonomi Pertanian. Program Pasca Sarjana Institut Pertanian Bogor, Bogor. Diunduh dari: 
http://repository.ipb.ac.id/bitstream/handle/123456789/46745/2011nqo.pdf.

(Diakses

pada tanggal 12 November 2016)

8. Robinson, L.J. and P.J Barry. 1987. The Competitive Firm's Respone to Risk. Macmilan Publisher, London.

9. Soekartawi. 2000. Teori Ekonomi Produksi dengan Pokok Bahasan Analisis Fungsi Cobb-Douglass. Rajawali Pers, Jakarta.

10. Suratiyah. 2011. Ilmu Usahatani. Penebar Swadaya. Jakarta.

11. Tasman, A. 2008. Analisis Efiseinsi and Produktivitas. Penerbit Chandra Pratama, Jakarta.

12. Weesink, A., A. Godah., and C.G. Turvey. 1990. Decomposition Measures of Tehnical Efficiency for Dairy Farms. Canadian Journal of Agricultural Economics, 38(3): 439-456. 